\title{
ASIMETRI PERSEPSI PENILAIAN KINERJA DAN PERILAKU DISFUNGSIONAL TIM: TINJAUAN TERHADAP PROFIL TIM
}

\author{
Supia Yuliana \\ Politeknik Sendawar \\ e-mail: adorapia@yahoo.com
}

\begin{abstract}
ABSTRAK
This paper introduced performance appraisal perception asymmetry construct on the team level management literature by integrated the performance appraisal perception and team behavior theories and researches. This paper proposed that performance appraisal perception asymmetry influenced the team dysfunctional behavior. Then, the author proposed that team structure might strengthened or weakened the performance appraisal perception asymmetry on the team dysfunctional behavior.
\end{abstract}

Keywords: performance appraisal perception asymmetry, dysfunctional behavior, team structure.

\begin{abstract}
PENDAHULUAN
Perilaku disfungsional identik dengan perilaku karyawan yang buruk yang mengacu pada setiap bentuk tindakan yang disengaja yang memiliki potensi untuk mempengaruhi organisasi dan karyawan yang lain seperti pencurian, sabotase terhadap aktivitas sosial, perilaku merusak, dan antisosial. Dalam kajian mengenai perilaku 'buruk' karyawan, Lawrence dan Robinson (2007) menyatakan bahwa prevalensi dan akibat dari kesalahan tersebut membuat studi tentang hal ini menjadi penting. Namun, penelitian tentang masalah ini umumnya terbatas pada menyelidiki bagaimana konteks individu membentuk perilaku disfungsional serta konsekuennya.

Seiring meningkatnya penggunaan tim dalam organisasi (Kozlowski dan Ilgen, 2006) dan berdasarkan penelitian Dunlop dan Lee (2004), yang menemukan bahwa perilaku disfungsional diperkirakan duapuluh empat persen dari varianvarian dalam kinerja unit serta penelitian Cole et al. (2008) yang mengawali penelitian kemungkinan
\end{abstract}

bahwa perilaku disfungsional antara anggota tim dapat memicu kerugian kinerja bagi tim secara keseluruhan, maka perilaku disfungsional dalam tim menjadi kebutuhan untuk dipahami (Cole et al., 2008).

Sistem penilaian kinerja di perusahaan atau organisasi merupakan bagian yang tidak terpisahkan dari suatu sistem manajemen kinerja yang memiliki tujuan secara khusus untuk membantu pengembangan karyawan. BoachieMensah dan Seidu (2012) menyatakan bahwa melakukan sistem penilaian dalam lingkungan berbasis tim menjadi rumit karena berbagai alasan, dan sangat penting bahwa sistem penilaian menyeimbangkan antara individu versus tim. Bahkan, Scott dan Einstein (2001) menyebutkan bahwa bukanlah rahasia lagi, banyak sistem penilaian kinerja gagal memberikan manfaat yang diharapkan dalam tim-terstruktur dalam organisasi. Sistem-sistem penilaian generik yang diterapkan hampir di seluruh organisasi telah mengabaikan perbedaan penting antara tim. Untuk meningkatkan kualitas penilaian kinerja, perlu untuk mempelajari tentang bagaimana persepsi 
penilaian kinerja tersebut dapat berpengaruh terhadap perilaku karyawan.

Dengan demikian, hubungan antara persepsi penilaian kinerja dalam tim dan perilaku disfungsional tim layak mendapatkan perhatian lebih, dan penulis berpendapat bahwa perbedaan penting tim yang diabaikan adalah perbedaan persepsi di dalam tim tentang penilaian kinerja. Beberapa penelitian tentang pentingnya persepsi penilaian kinerja karyawan yang mengarah pada hasil telah dilakukan namun belum mempelajari perbedaan persepsi penilaian kinerja anggota tim yang mengarahkan anggota tim berperilaku disfungsional dalam tim. Selain itu, penulis berpendapat bahwa perbedaan struktur tim akan menentukan juga hasil dari perbedaan persepsi terhadap efeknya pada perilaku disfungsional.

Dalam tulisan ini, penulis berupaya untuk memberi kontribusi pada literatur persepsi penilaian kinerja yaitu: pertama, penulis mencoba menghasilkan konsep penting hubungan langsung antara persepsi penilaian kinerja terhadap perilaku disfungsional tim; kedua, penulis mencoba memperluas literatur tentang perlunya memperhatikan perbedaan persepsi di dalam tim yang dapat berpengaruh pada perilaku yang dapat mewakili sebagai perilaku tim secara keseluruhan, meski perbedaan profil tim juga dianggap menjadi penentu hubungan antara persepsi penilaian kinerja terhadap perilaku disfungsional.

\section{REVIEW LITERATUR DAN HIPOTESIS}

Dalam organisasi modern, tim telah menjadi metode pilihan untuk merespon dengan cepat terhadap perubahan teknologi dan pasar dan dengan demikian meningkatkan kesempatan organisasi untuk bertahan hidup (Ilgen et al., 2005). Berbagai penelitian dan upaya telah diinvestasikan untuk memahami bagaimana menciptakan dan mengembangkan tim yang efektif (Somech et al., 2009).
Pengembangan karyawan dalam berbagai bentuk merupakan syarat mutlak tercapainya suatu organisasi yang memiliki daya saing tinggi. Karena itu, sangat diperlukan suatu sistem penilaian kinerja yang mampu memenuhi fungsifungsinya secara utuh dalam kaitannya dengan peningkatan kualitas sumber daya manusia. Tidak hanya bagi karyawan, namun sistem penilaian kinerja juga sangat diperlukan organisasi agar dapat menampilkan gambaran secara menyeluruh mengenai kondisi ketenagakerjaan suatu organisasi dalam rangka pencapaian tujuan organisasi.

Persepsi karyawan tentang proses, hasil, sasaran, dan penggunaan hasil penilaian kinerja menjadi faktor penting karena dapat memberikan kontribusi yang menguntungkan bahkan sebaliknya. Karyawan cenderung untuk merangkul dan memberikan kontribusi yang bermanfaat bagi skema penilaian kinerja yang diberikan jika mereka melihatnya sebagai kesempatan untuk promosi, dan sebagai jalan untukpeluangpengembangan pribadi, kesempatan untuk terlibat dan menunjukkan keterampilan dan kemampuan, dan kesempatan untuk membentuk dan memperluas jaringan dengan orang lain dalam organisasi. Di sisi lain, jika karyawan menganggap penilaian kinerja sebagai upaya yang tidak masuk akal oleh manajemen untuk melakukan pengawasan lebih dekat dan kontrol atas tugas-tugas mereka (karyawan), berbagai reaksi dapat terjadi bahkan penilaian kinerja bisa berubah menjadi kontraproduktif (BoachieMensah dan Seidu, 2012).

Selain manfaat penilaian kinerja yang begitu besar sebagai bagian penting dalam organisasi, tidak dapat dipungkiri bahwa terdapat banyak permasalahan dalam penilaian aktual kinerja karyawan (Corbett dan Kenny, 2001; dalam Boachie-Mensah dan Seidu, 2012). Banyak penelitian kelompok berfokus pada sifat bersama tim, atau pengalaman dan persepsi yang diyakini bersama oleh anggota tim (Klein dan Kozlowski, 
2000) yang sering mengabaikan keberadaan varian-varian dalam tim (Jehn et al., 2010)

Fenomena kemalasan sosial muncul di dalam tim, di mana kemalasan sosial ini dapat menyebar di antara anggota tim yang pada akhirnya akan meracuni iklim kerja (Scott dan Einstein, 2001). Hal ini sejalan dengan apa yang disebut di sini sebagai perilaku difungsional tim yang disebabkan oleh perbedaan persepsi penilaian kinerja. Penulis sepakat dengan pendapat Scott dan Einstein (2001) bahwa efek dari perilaku disfungsional tim tersebut akan menyebar pada seluruh tim pada akhirnya akan berpengaruh pada kinerja tim secara keseluruhan. Kajian yang dilakukan oleh Cole et al. (2008) membuktikan bahwa hubungan antara perilaku disfungsional tim yang dapat memicu kerugian kinerja tim secara keseluruhan merupakan upaya mengisi kesenjangan penelitian dalam memahami faktor-faktor penentu perilaku disfungsional yang umumnya terbatas pada menyelidiki bagaimana konteks tim individu membentuk perilaku disfungsional mereka (mis., Robinson dan O〉Leary-Kelly, 1998).

\section{Perilaku Disfungsional Tim}

Perilaku disfungsional tim dapat dibayangkan atau digambarkan berasal dari tindakan mengganggu satu individu tapi diwujudkan sebagai properti bersama tim melalui interaksi timbal-balik anggota-anggota tim (Kozlowski dan Klein, 2000). Oleh karena itu, perilaku disfungsional tim berbeda dalam struktur (tapi tidak dalam fungsi) dari perilaku disfungsional tingkat-individu (Morgeson dan Hofmann, 1999). Berdasarkan logika ini, perilaku disfungsional tim diperdebatkan untuk mencerminkan tingkat ambien negatif, perilaku mengganggu yang menyerap konteks tim (Hackman, 1992).

Felps et al. (2006) berpendapat bahwa bahkan satu anggota yang mengganggu dapat menjadi katalisator bagi disfungsi tingkat-tim.
Skenario ini paling sering terjadi ketika anggota tim yang lain kurang kuat (power) dibandingkan anggota yang disfungsional, sehingga membatasi munculnya tanggapan konstruktif (misalnya, reformasi atau penolakan dari individu disfungsional, Felps et al., 2006). Dalam situasi ini, jalan yang paling mungkin oleh rekan adalah bertindak membela diri. Meskipun demikian, respon defensif biasanya gagal menyelesaikan masalah perilaku disfungsional dalam tim. Sebaliknya, tindakan disfungsional dapat semakin intensif dan menyebar ke seluruh tim ketika anggota mencoba untuk membela diri dan tim melalui upaya pembalasan atau balas dendam (Bies et al., 1997), dan berpotensi menghasilkan spiral perilaku disfungsional (Andersson dan Pearson, 1999).

\section{Persepsi Penilaian Kinerja}

Meskipun penilaian kinerja telah dirancang untuk mengembangkan instrumen yang paling sesuai untuk mengukur kinerja, namun masih terdapat masalah ketidakpuasan karyawan dalam implementasi sistem tersebut. Karyawan memiliki persepsi yang berbedabeda terhadap penilaian kinerja. Karyawan yang memiliki penilaian tinggi terhadap penilaian kinerja akan berpendapat bahwa sistem tersebut efektif dan efisien sehingga berpersepsi positif; dan sebaliknya. Persepsi negatif karyawan terhadap penilaian kinerja akan memengaruhi persepsi mereka terhadap kinerja pekerjaan, menjadi terdemotivasi, dan berkinerja buruk (Gabris dan Mitchell, 1989).

Lawrie (1990) berasumsi bahwa penilaian kinerja merupakan aspek dalam organisasi yang paling sulit dan kritis. Menurut Derven (1990), banyak bukti yang ditunjukkan baik oleh para peneliti, manajer, dan ahli psikometri yang meragukan efektifitas dan efisiensi dari sistem penilaian kinerja, dan menganggap bahwa sistem tersebut bias, diimplementasikan secara tidak adil, dan membangun persepsi negatif terhadap sistem 
penilaian kinerja itu sendiri. Dengan demikian, penilaian kinerja dapat menjadi produktif maupun kontraproduktif, dan salah satu faktor penentunya adalah persepsi karyawan, baik secara individu maupun tim, terhadap penilaian kinerja.

Penelitian empiris telah banyak menunjukkan bahwa dalam seting organisasi, persepsi-persepsi tertentu, misalnya persepsi ketidaktentuan dan persepsi ketidakadilan, berhubungan dengan perilaku dan sikap individu. Konsep relevan lainnya dalam hubungan dengan persepsi adalah 'tindakan'. Tindakan mengacu pada aktivitas seseorang sebagai tanggapan terhadap proses perseptual. Argyris (1999) menyatakan bahwa, individu memiliki jenis program mental tertentu untuk bagaimana bertindak secara efektif dalam jenisjenis interaksi yang berbeda; dan terdapat dua teori tindakan individu: yang pertama biasanya diekspresikan dalam bentuk keyakinan dan nilai yang dinyatakan, dan yang kedua adalah yang digunakan secara aktual dan hanya dapat diketahui dengan mengamati perilaku-perilaku individu.

Memahami keadilan organisasional dalam proses dan praktik penilaian kinerja sangat penting bagi organisasi karena hal itu berhubungan erat dengan kepuasan dan komitmen karyawan dan keinginan turnover. Cropanzano, Bowen, and Gillian (2007) mendefinisikan keadilan organisasional sebagai evaluasi personal tentang etika dan moral dari tindakan manajerial. Mereka berpendapat bahwa keadilan organisasional berpotensi menciptakan keuntungan bagi organisasi dan menyenangkan karyawan. Fullford (2005) menyatakan bahwa konsep keadilan organisasional adalah konstruk multidimensional yang menjelaskan peran keadilan dalam suatu konteks organisasional. Cremer (2005) mengusulkan bahwa interaksi antara keadilan prosedural dan distributif paling mungkin diamati ketika karyawan menunjukkan sense of affiliation yang kuat terhadap organisasinya. Secara khusus, apa yang dirasakan adil oleh seseorang tergantung pada pengalamannya atas opini-opini tentang cara-cara yang pantas menuju hasilhasil distributif dan memperlakukan orang lain (Greenberg, 2001). Keadilan telah lama dianggap sebagai salah satu prediktor kunci dari keadaankeadaan dan perilaku afektif karyawan. Ketika karyawan merasa diperlakukan secara adil, mereka akan membalasnya melalui kepuasan dan komitmen; dan sebaliknya, jika karyawan merasa diperlakukan secara tidak adil, mereka mungkin akan membalas dengan tindakan atau perilaku yang kontraproduktif dan merugikan organisasi.

\section{Profil Persepsi Tim}

Dengan merujuk pada profil tim yang diajukan dalam proposisi Barnes dan Hollenbeck (2009), penulis membangun profil persepsi tim yang digunakan dalam tulisan ini, di mana tim bisa terdiri dari kombinasi beberapa anggota yang memiliki persepsi penilaian kinerja yang simetrik positif dan simetrik negatif, penyederhanaan beberapa kombinasi dengan menciptakan kategori tim berdasarkan profil simetrik persepsi yang mengarah pada tindakan kontraproduktif. Tulisan ini mempertimbangkan lima kategori yaitu: ekstrim (1) sepenuhnya anggota tim berpersepsi simetrik positif terkait penilaian kinerja; dan (2) anggota tim berpersepsi simetrik negatif terkait penilaian kinerja. Selain kasuskasus yang ekstrim, banyak tim akan terdiri dari campuran anggota berpersepsi simetrik positif dan berpersepsi simetrik negatif. (3) Anggota tim berpersepsi negatif didefinisikan terdiri dari kurang dari 50 persen anggota tim berpersepsi positif. Konfigurasi ini sangat penting karena, dalam kondisi tertentu, tim berperilaku seperti mayoritas anggotanya (Laughlin, 1999; dalam Barnes dan Hollenbeck (2009).

Seperti yang menjadi dasar Barnes dan Hollenbeck (2009) dalam mengkategorisasi tim, berikutnya adalah bahwa terdapat konteks tugas di mana anggota berkinerja terbaik dan terburuk 
yang akan menentukan hasil tim (Steiner, 1972). Menggunakan terminologi Steiner, efek ini dapat dilihat sebagai efek penghubung dan efek disjungtif. Artinya, dengan tugas penghubung dampak dari anggota tim berpersepsi simetrik negatif tunggal dapat membuat grup tampil lebih seperti sebuah tim anggota tim berpersepsi simetrik negatif penuh, dan dengan tugas disjungtif dampak satu anggota anggota tim berpersepsi simetrik positif dapat membuat tim bertindak lebih seperti sepenuhnya tim berpersepsi simetrik positif. Dengan demikian, untuk mempertimbangkan efek seperti itu, dimasukkan kategori: (4) kelompok dengan satu anggota tim berpersepsi positif; dan (5) kelompok dengan satu anggota tim berpersepsi negatif untuk sepenuhnya menggambarkan lima jenis tim yang relevan dalam kerangka ini. Singkatnya, lima konfigurasi tersebut adalah: dari paling sedikit tim berpersepsi negatif, terdiri dari sepenuhnya tim berpersepsi simetrik negatif, salah satu anggota berpersepsi positif, mayoritas berpersepsi simetrik negatif, salah satu anggota berpersepsi negatif, dan sepenuhnya berpersepsi simetrik positif terkait penilaian kinerja.

Penulis juga merujuk pada empat efek khusus yang mungkin timbul dari kombinasi tim yang diusulkan Barnes dan Hollenbeck (2009), di mana efek-efek khusus tersebut meliputi: (1) efek diabaikan (dampak kecil terlepas dari jumlah anggota berpersepsi simetrik negatif); (2) efek disjungtif (kehadiran anggota tim berpersepsi positifakan mengimbangi efek negatif berpersepsi negatif); (3) efek linear negatif (lebih banyak berpersepsi simetrik negatif, akan menghasilkan kinerja yang buruk); dan, (4) efek penghubung (adanya satu anggota tim berpersepsi simetrik negatif tunggal akan menghasilkan kinerja yang buruk).

\section{Struktur Tim: Diferensiasi Vertikal dan Horisontal}

Struktur sebuah tim mencerminkan bagaimana upaya individu diarahkan pada pemenuhan tugas yang dibedakan dan kemudian diintegrasikan. Penelitian sebelumnya menunjukkan bahwa ada dua dimensi penting dari struktur, yaitu: horisontal dan vertikal (Burns dan Stalker, 1961). Dimensi diferensiasi horisontal, menghambat distribusi keahlian dan informasi di antara anggota tim. Tim terdiri dari anggota dengan keahlian identik dan informasi yang rendah dalam diferensiasi, serta tim terdiri dari anggota dengan keahlian yang sangat khusus dan informasi yang tinggi dalam diferensiasi (Budescu et al., 2003).

Sedangkan dimensi diferensiasi vertikal, menghambat distribusi kekuasaan di antara anggota tim. Tim yang terdiri dari anggota tim dengan tingkat kekuasaan yang setara dalam pengambilan keputusan akan rendah dalam diferensiasi vertikal, tim seperti itu sering bergantung pada konsensus atau aturan mayoritas proses keputusan untuk mengubah preferensi individu menjadi keputusan tunggal tim. Sebaliknya, tim dengan diferensiasi vertikal yang tinggi memiliki satu pemimpin terpusat (baik formal maupun informal) dengan akuntabilitas yang tidak proporsional dan pengaruh terhadap pengambilan keputusan (Hollenbeck et al., 1995).

\section{Diferensiasi Horisontal dan Substitutabilitas}

Anggota-anggota tim simetris (atau homogen) ketika mereka dibedakan dari segi keahlian, jumlah bukti yang mereka miliki, atau ciri pembeda lain yang relevan (Budescu et al., 2003). Contoh dari tim simetris, misalnya tim akuntan dengan pelatihan serupa yang diberi informasi terbuka dan dibagi di antara semua anggota. Fitur kunci dari tim simetris dalam konteks perbedaan persepsi penilaian kinerja 
yang mengarah pada perilaku disfungsional tim adalah bahwa tidak ada yang mencegah salah satu anggota tim untuk mampu mengambil alih tanggung jawab dari seorang anggota tim yang berpersepsi negatif. Sebaliknya, para pengambil keputusan dengan keahlian atau informasi yang tidak overlapping dianggap asimetris.

Membedakan tingkat substitusi horisontal memiliki implikasi penting dalam organisasi karena pengambilan keputusan kelompok didasarkan pada informasi yang tidak sepenuhnya bersama seluruh anggota kelompok (Gigone dan Hastie, 1997). Dengan demikian, ketika anggota tim tinggi dalam substitusi, jika salah satu anggota tim memiliki persepsi negatif terhadap penilaian kinerja, di mana tim masih dapat mengakses keahlian dan informasi kritis dari anggota tim lainnya. Tim masih mungkin mengalami penurunan karena kontribusi anggota yang berkurang, namun masih bisa efektif karena redundansi dari keahlian dan informasi dalam tim. Selama ada setidaknya satu anggota tim yang berpersepsi positif, semua informasi yang diperlukan dan keahlian tersedia, maka tim memiliki potensi untuk mencapai solusi yang tepat. Hal ini menunjukkan efek disjungtif dari persepsi negatif penilaian kinerja pada akurasi pembuatan keputusan tim.

Sebaliknya, ketika kontribusi anggota tim adalah khusus dan rendah substitusi, pengaruh persepsi negatif penilaian kinerja terjadi lebih cepat. Bahkan, jika persepsi negatif penilaian kinerja menyebabkan anggota tim yang memegang keahlian atau informasi unik tidak membuat kontribusi kunci, tim tidak memiliki cara lain untuk mendapatkan kontribusi kunci tersebut. Dengan demikian, jika ada satu anggota tim tidak memberikan kontribusi kunci karena persepsi negatif dan berperilaku disfungsional, maka tim akan mengalami penurunan besar, menunjukkan efek penghubung dari persepsi negatif pada akurasi pembuat keputusan. Oleh karena itu, penulis mengusulkan:
Proposisi 1. Dalam tim dengan substitusi tinggi, selama terdapat setidaknya satu anggota tim yang berpersepsi positif terkait penilaian kinerja, akan menunjukkan efek disjungtif dari persepsi negatif terkait penilaian kinerja

Proposisi 2. Dalam tim dengan substitusi rendah, jika ada satu anggota tim memiliki persepsi negatif terkait penilaian kinerja maka akan menunjukkan efek penghubung dari persepsi negatif asimetri dengan perilaku disfungsional.

\section{Diferensiasi Vertikal dan Status}

Di dalam tim, preferensi dan pendapat ganda harus diubah menjadi satu keputusan atau solusi tunggal yang diusulkan untuk tim secara keseluruhan. Salah satu faktor penting dalam bagaimana suara-suara yang saling bertentangan menjadi keputusan akhir adalah tingkat pengaruh anggota tim (Bacharach dan Lawler, 1981). Penelitian sebelumnya telah mendokumentasikan dengan jelas bahwa kekuasaan dan status mungkin tidak merata dalam tim karena alasan formal yang harus dilakukan oleh otoritas yang sah, serta untuk alasan informal yang terkait dengan popularitas, extraversion, atau keahlian yang dapat dipisahkan dari hirarki formal. Faktorfaktor ini, bersama dengan penggunaan taktik perilaku diferensial (Cable dan Judge, 2003; Yukl dan Falbe, 1991; Yukl et al., 1996), posisi individu dalam jaringan interpersonal (Brass dan Burkhardt, 1993), dan basis kekuasaan lainnya dalam tim (French dan Raven, 1959; Hinkin dan Schriesheim, 1989), dapat mengakibatkan heterogenitas dalam pengaruh. Heterogenitas pengaruh dapat merusak kemampuan untuk membuat prediksi linier sederhana mengenai pengaruh persepsi negatif pada hasil tim.

Dalam tim dengan diferensiasi vertikal tinggi, satu individu menentukan keputusan 
untuk tim, seringkali setelah mencari masukan dari anggota kelompok lain tetapi tanpa harus mencapai konsensus atau melakukan vote (Hollenbeck et al., 1998; Hollenbeck et al., 1995). Dalam tim dengan diferensiasi vertikal rendah, anggota lebih setara dalam kekuasaan mereka untuk memengaruhi tim, seperti yang sering diasumsikan dalam penelitian tentang swakelola atau tim juri (mis., Kirkman dan Shapiro, 2001). Tim dengan diferensiasi vertikal yang rendah cenderung mengandalkan pengembangan konsensus atau, jika gagal, metode voting untuk sampai pada keputusan untuk tim secara keseluruhan. Karena anggota tim memiliki kekuatan yang relatif setara dalam kondisi diferensiasi vertikal rendah, diusulkan efek linear negatif untuk persepsi negatif yang mengarah pada perilaku disfungsional tim.

Sebaliknya, dalam tim dengan diferensiasi vertikal tinggi, pertimbangan utama adalah anggota tertentu yang memiliki persepsi penilaian kinerja negatif. Dalam tim yang sangat dibedakan secara vertikal, kekuatan (power) yang tinggi dari satu anggota tim dapat mengubah atau mengesampingkan solusi yang diusulkan oleh anggota tim lainnya. Jika pemimpin formal maupun informal dari sebuah tim berpersepsi positif, ia mungkin dapat mengurangi kesalahan dalam keputusan, memeriksa alternatif yang tidak dipertimbangkan oleh anggota tim lain, atau memeriksa sumber informasi. Hal ini akan menyebabkan efek disjungtif untuk kelompok meski hanya memiliki satu orang yang berpersepsi positif sedang yang lainnya berpersepsi negatif. Atau, jika pemimpin adalah orang yang berpersepsi negatif, ia dapat memperkenalkan perilaku disfungsional dan yang lain tidak berdaya untuk mencegah atau menolak. Dalam kondisi ini terjadi efek penghubung, di mana anggota tim juga melakukan perilaku disfungsional tersebut. Oleh karena itu, penulis mengusulkan:

Proposisi 3a. Dalam tim dengan diferensiasi vertikal tinggi, jika pemimpin formal maupun informal dari sebuah tim berpersepsi positif terkait penilaian kinerja akan menyebabkan efek disjungtif meski anggota lainnya berpersepsi negatif terhadap penilaian kinerja.

Proposisi 3b. Dalam tim dengan diferensiasi vertikal tinggi, jika pemimpin formal maupun informal dari sebuah tim berpersepsi negatif terkait penilaian kinerja akan menyebabkan terjadi efek penghubung terhadap anggota lainnya untuk berperilaku disfungsional.

Proposisi 4. Dalam tim dengan diferensiasi vertikal rendah akan berefek linier negatif untuk persepsi negatif terkait penilaian kinerja yang mengarah pada perilaku disfungsional tim.

\section{Hubungan Persepsi Penilaian Kinerja, Perilaku Disfungsional Tim, dan Profil Tim}

Berdasarkan pandangan bahwa ada persepsi yang berbeda dari realitas yang sama telah menjadi dasar bagi banyak penelitian sosial kognisi (Bruner, 1957). Teori kognitif sosial (Social cognitive theory) (Bandura, 2001) dan pendekatan pengolahan informasi sosial (Social information processing approach) (Salancik dan Pfeffer, 1978) telah digunakan untuk menjelaskan pengalaman yang berbeda dari individu-individu dalam organisasi. Selain itu, kelompok (tim) memiliki sifat berbagi (Klein dan Kozlowski, 2000; Mason, 2006), seperti emosi (mis., Mason, 2006; Totterdell et al., 1998), sikap (mis., Mason dan Griffin, 2003), dan persepsi (mis., CannonBowers et al., 1993; Klimoski dan Mohammed, 1994). Ini merupakan asumsi yang masuk akal mengingat penelitian-penelitian klasik menunjukkan bahwa individu sering bertemu 
dengan realitas yang sama ketika ditempatkan dalam situasi sosial (Sherif, 1935). Namun, ada juga sejumlah besar penelitian menunjukkan bahwa terdapat asimetri persepsi dan pengalaman yang ada dalam kelompok. Perbedaan tersebut telah ditemukan dalam studi jaringan sosial mengenai inkonsistensi kognitif dan asimetri dalam hubungan diad (Carley dan Krackhardt, 1996; Casciaro et al., 1999), serta dalam penelitian yang menunjukkan bahwa individu dalam negosiasi dan permainan eksperimental menyertakan interpretasi yang berbeda untuk situasi yang sama (Sattler dan Kerr, 1991; Van Lange dan Kuhlman, 1994) dan bahwa individu dengan tingkat kekuatan yang berbeda memiliki pengalaman yang berbeda dalam kelompok selama kinerja tugas (mis., Galinsky et al., 2006; Guinote et al., 2002).

Penelitian tentang keanekaragaman dan demografi relasional dalam organisasi juga menunjukkan bahwa karyawan memiliki respons berbeda terhadap lingkungan mereka (Chatman dan Spataro, 2005; Cronin dan Weingart, 2007; Tsui, Egan, dan O'Reilly, 1992) karena mereka mungkin menganggap diri mereka berbeda (Lawrence, 1997; Riordan, 2000). Secara spesifik, berdasarkan uraian di atas penulis berasumsi bahwa anggota tim memiliki persepsi penilaian kinerja yang berbeda, oleh karenanya penulis mengusulkan bahwa penting untuk mempertimbangkan perbedaan persepsi dalam teori lanjutan tentang kelompok dan untuk menambah penjelasan teoritis mengenai persepsi penilaian kinerja dalam kelompok kerja.

Pada uraian Shrivastava dan Purang (2011) yang mengutip kajian Bretz et al., (1992) tentang penilaian kinerja, yang menunjukkan bahwa keadilan yang dirasakan dari sistem penilaian kinerja telah muncul sebagai isu yang paling penting yang harus dihadapi oleh manajer. Persepsi keadilan memegang tempat penting dalam organisasi karena mencegah konsekuensi negatif seperti pencurian, sabotase, dan perilaku mengganggu lainnya dan meningkatkan hasil positif seperti OCB, komitmen, dan kepuasan kerja. Persepsi keadilan memengaruhi cara orang berpikir, merasa, dan bertindak pada pekerjaan (Bies dan Shapiro, 1987). Sehingga, persepsi keadilan tentang sistem penilaian kinerja akan memengaruhi reaksi afektif positif seperti kepuasan penilaian kinerja (Thurston, 2001; Cook dan Crossman, 2004). Di sini penulis berasumsi bahwa perbedaan persepsi penilaian kinerja pada tim akan menghasilkan konsekuensi perilaku yang berbeda pula. Secara khusus tulisan ini merujuk pada konsekuensi dari persepsi penilaian kinerja yang negatif yaitu perilaku disfungsional.

Pengaturan tim juga menyediakan banyak kesempatan untuk mengamati perilaku anggota lain. Anggota tim dapat belajar untuk terlibat dalam perilaku disfungsional dengan mengamati rekan lain dan kemudian menyadari pemodelan tindakan ini (Bandura, 1973). Suatu mekanisme transmisi yang sebanding disebut efek spillover. Penelitian menunjukkan, misalnya, bahwa ketika orang melihat rekan bertindak secara disruptif, perilaku mental menjadi lebih mudah diakses, dan individu menjadi lebih mudah untuk berperilaku dengan cara yang sama (Felps et al., 2006; Keyton, 1999). Demikian juga, literatur tentang kelompok (tim) menggambarkan agresi spillover sebagai 'agresi menular', di mana tindakan agresif memantul ke seluruh tim (Folger dan Skarlicki, 1998; Glomb dan Liao, 2003).

Teori pengolahan informasi sosial berpendapat bahwa konteks sosial memengaruhi harapan sadar individu mengenai perilaku mereka sendiri (Salancik dan Pfeffer, 1978). Menurut perspektif ini, anggota tim menggunakan isyarat dalam lingkungan sosial mereka untuk menentukan sejauh mana perilaku disfungsional yang sesuai. Isyarat ini mungkin berasal dari norma-norma dan harapan tim, serta perilaku anggota tim lainnya. Selain itu, ketika menghadapi perilaku disfungsional, seseorang mungkin dapat mencari interpretasi rekan tim untuk membantu 
memahami perilaku tersebut. Hal ini dapat menyebabkan berbagi sosial sekunder, di mana mereka yang baru saja mempelajari tindakan disfungsional dengan sendirinya cenderung untuk berbagi dengan orang lain apa yang telah mereka dengar (Rime, 2007). Seiring waktu, kemudian, anggota tim menerima isyarat-isyarat sosial umum yang meyakinkan mereka bahwa perilaku disfungsional adalah respon yang diterima oleh kondisi kerja bersama (Robinson dan O'LearyKelly, 1998). Dengan demikian, kita dapat menyimpulkan bahwa perilaku disfungsional anggota tim dapat menyebar ke seluruh tim dalam berbagai cara, baik secara tidak sadar dan sadar.

Meski secara konseptual telah diuraikan bagaimana perbedaan persepsi penilaian kinerja dapat berefek pada perilaku disfungsional serta perilaku disfungsional dapat menyebar di dalam tim, namun dari berbagai profil tim yang menjadi dasar proposisi sebelumnya telah menunjukkan bahwa secara keseluruhan efek dari perbedaan persepsi terhadap perilaku disfungsional berbedabeda. Oleh karena itu secara umum penulis mengusulkan:

Proposisi 5. Perbedaan persepsi tentang penilaian kinerja dapat berhubungan dengan perilaku disfungsional tim namun efeknya masing-masing tergantung pada profil tim di mana tim tersebut terbentuk.

\section{KESIMPULAN DAN SARAN}

Perilaku disfungsional tim belum menjadi perhatian dalam pernelitian persepsi penilaian kinerja. Penelitian tentang persepsi penilaian kinerja pada tim yang ada masih menganggap bahwa tim memiliki persepsi yang sama sehingga mengabaikan perbedaan persepsi anggota di dalam tim

Persepsi negatif tentang penilaian kinerja dapat berpengaruh langsung terhadap perilaku disfungsional tim, namun efeknya terhadap perilaku disfungsional tim tergantung pada struktur tim dimana profil tim tersebut dibentuk. Model konseptual yang disediakan dalam tulisan ini menunjukkan hasil bahwa tim dengan diferensiasi horisontal subtitusi rendah akan menimbulkan efek penghubung, sedang tim dengan diferensiasi horisontal subtitusi tinggi akan menimbulkan efek disjungtif.

Selain itu tim dengan diferensiasi vertikal status tinggi, jika pemimpin memiliki persepsi penilaian kinerja negatif maka akan menimbulkan efek penghubung, namun jika pemimpin memiliki persepsi penilaian kinerja positif maka akan menimbulkan efek disjungtif. Dan, tim dengan diferensiasi vertikal yang rendah akan menyebabkan efek linear negatif untuk persepsi penilaian kinerja negatif yang mengarah pada perilaku disfungsional tim.

\section{DAFTAR PUSTAKA}

Andersson, L. M., \& Pearson, C. M. 1999. Tit for tat? The spiraling effect of incivility in the workplace. Academy of Management Review, 24, 452-471.

Bacharach, S. B., \& Lawler, E. J. 1981. Power and tactics in bargaining. Industrial \& Labor Relations Review, 34: 219-233.

Bandura, A. (1973). Aggression: A social learning analysis. Englewood Cliffs, NJ: Prentice Hall.

Bandura, A. 2001. Social cognitive theory: An agentic perspective. In S. T. Fiske, D. L. Schacter, \& C. Zahn-Wexler (Eds.). Annual review of psychology. vol. 52: 1-26. Palo Alto, CA: Annual Reviews.

Barnes, C.M., \& Hollenbeck, J.R. 2009. Sleep Deprivation and decision-Making Teams: Burning The Midnight Oil or Playing with Fire? Academy of Management Review. Vol. 34, No. 1, 56-66. 
Bies, R.J., and Shapiro, D.L. (1987), 'Interaction Fairness Judgments: The Influence of Causal Accounts,' Social Justice Research, 1, 199-218.

Bies, R. J., Tripp, T. M., \& Kramer, R. M. 1997. At the breaking point: Cognitive and social dynamics of revenge in organizations. In R. A. Giacalone \& J. Greenberg (Eds.), Antisocial behavior in organizations (pp. 18-36). Thousand Oaks, CA: Sage.

Boachie-Mensah., \& Seidu. 2012. Employees's Perception of Performance Appraisal System: A Case Study. Intemational Joumal of Business and Management. Vol. 7, No. 2; January 2012

Bruner, J. S. 1957. On perceptual readiness. Psychological Review. 64: 123-152.

Budescu, D. V., Rantilla, A. K., Yu, H. T., \& Karelitz, T. M. 2003. The effects of asymmetry among advisors on the aggregation of their opinions. Organizational Behavior and Human Decision Processes, 90: 178-194.

Burns, T., \& Stalker, G. M. 1961. The management of innovation. London: Tavistock.

Cable, D. M., \& Judge, T. A. 2003. Managers' upward influence tactic strategies: The role of manager personality and supervisor leadership style. Journal of Organizational Behavior, 24: 197-214.

Cannon-Bowers, J. A., Salas, E., \& Converse S. 1993. Shared mental models in expert team decision making. In N. J. Castellan Jr. (Ed.), Individual and group decision making: Current issues: 221-246. Hillsdale, NJ: Erlbaum.

Carley, K. M., \& Krackhardt, D. 1996. Cognitive inconsistencies and non-symmetric friendship. Social Networks 18:1-27.

Casciaro, T., Carley, K. M., \& Krackhardt, D. 1999. Positive affectivity and accuracy in social network perception, Motivation and Emotion, 23: 285-306.
Chatman, J. A., \& Spataro, S. E. 2005. Using self-categorization theory to understand relational demography-based variations in people's responsiveness to organizational culture. Academy of Management Journal, 48: 321-331.

Cole, Michael S., Walter. Frank, \& Bruch, Heike. 2008. Affective Mechanisms Linking Dysfunctional Behavior to Performance in Work Teams: A Moderated Mediation Study. Journal of Applied Psychology. Vol. 93, No. 5, 945-958

Cook, J., and Crossman, A. (2004), 'Satisfaction with Performance Appraisal Systems: A Study of Role Perceptions,' Journal of Managerial Psychology, 19, 5, 526-541.

Cronin, M. A., \& Weingart, L. R. 2007. Representational gaps, information processing, and conflict in functionally diverse teams. Academy of Management Review, 32: 761-773.

Cropanzano, R. \& Mitchell, M. S. 2005. Social Exchange Theory: An Interdisciplinary Review. Journal of Management. 31(6), 874-900.

Dunlop, P. D., \& Lee, K. 2004. Workplace deviance, organizational citizenship behavior, and business unit performance: The bad apples do spoil the whole barrel. Journal of Organizational Behavior. 25, 67-80.

Felps, W., Mitchell, T. R., \& Byington, E. 2006. How, when, and why bad apples spoil the barrel: Negative group members and dysfunctional groups. In B. M. Staw (Ed.), Research in organizational behavior (Vol. 27, pp. 175-222). Amsterdam: Elsevier.

Folger, R., \& Skarlicki, D. P. (1998). A popcorn metaphor for workplace violence: In R. W. Griffin, A. O’Leary-Kelly, \& J. Collins (Eds.), Dysfunctional behavior in organizations: Violent and 
deviant behavior (Vol. 23, pp. 43-81) [Monographs in organizational behavior and relations]. Greenwich, CT: JAI Press

French, J. R. P., \& Raven, B. 1959. The bases of social power. In D. Cartwright \& A. Zander (Eds.), Group dynamics: 150167. New York: Harper \& Row.

Galinsky, A. D., Magee, J. C., Ena Inesi, M., \& Gruenfeld, D. H. 2006. Power and perspectives not taken. Psychological Science 17: 1068-1074.

Gigone, D., \& Hastie, R. 1997. The impact of information on small group choice. Journal of Personality and Social Psychology, 72: 132-140.

Glomb, T. M., \& Liao, H. (2003). Interpersonal aggression in work groups: Social influence, reciprocal, and individual effects. Academy of Management Journal, 46, 486-496.

Guinote, A., Judd, C. M., \& Brauer, M. 2002. Effects of power on perceived and objective group variability: Evidence that more powerful groups are more variable. Journal of Personality and Social Psychology, 82: 708-721.

Hackman, J. R. 1992. Group influences on individuals in organizations. In M. D. Dunnette \& L. M. Hough (Eds.), Handbook of industrial and organizational psychology. Vol. 3, pp. 199-267. Palo Alto, CA: Consulting Psychologists Press.

Hinkin, T. R., \& Schriesheim, C. A. 1989. Development and application of new scales to measure the French and Raven (1959) bases of social power. Journal of Applied Psychology, 74: 561-567.

Hollenbeck, J. R., Ilgen, D. R., Sego, D. J., Hedlund, J., Major, D. A., \& Phillips, J. 1995. Multilevel theory of team decision-making-Decision performance in teams incorporating distributed expertise. Journal of Applied Psychology, 80: 292-316.

Ilgen, D. R., Hollenbeck, J. R., Johnson, M., \& Jundt, D. (2005). Teams in organizations: From input-process-output models to IMOI models. Annual Review of Psychology, 56, 517-543

Jehn, K. A., Rispens, S., Thatcher, Sherry M.B. 2010. The Effects of Conflict Asymmetry on Work Group and Individual Outcomes. Academy of Management Journal. Vol. 53, No. 3, 596-616.

Keyton, J. (1999). Analyzing interaction patterns in dysfunctional teams. Small Group Research, 30, 491-518.

Klimoski, R. J., \& Mohammed, S. 1994. Team mental model: Construct or metaphor? Journal of Management, 20: 403-437.

Kozlowski, S. W. J., \& Klein, K. J. (2000). A multilevel approach to theory and research in organizations: Contextual, temporal, and emergent processes. In K. J. Klein \& S. W. J. Kozlowski (Eds.), Multilevel theory, research and methods in organizations: Foundations, extensions, and new directions (pp. 3-90). San Francisco: Jossey-Bass.

Kozlowski, S. W. J., \& Ilgen, D. R. 2006. Enhancing the effectiveness of work groups and teams. Psychological Science in the Public Interest, 7, 77-124.

Lawrence, B. S. 1997. The black box of organizational demography. Organization Science, 8: 1-22.

Lawrence, T. B., \& Robinson, S. L. 2007. Ain't misbehavin: Workplace deviance as organizational resistance. Journal of Management. 33, 378-394.

Mason, C. M., \& Griffin, M. A. 2003. Identifying group task satisfaction at work. Small Group Research, 34: 413-442. 
Mason, C. M. 2006. Exploring the processes underlying within-group homogeneity. Small Group Research, 37: 233-270.

Morgeson, F. P., \& Hofmann, D. A. 1999. The structure and function of collective constructs. Academy of Management Review, 24, 249-265.

Riordan, C. M. 2000. Relational demography within groups: Past developments, contradictions, and new directions. In G. R. Ferris (Ed.), Research in personnel and human resources management, vol. 19: 131-173. Greenwich, CT: JAI Press.

Robinson, S. L. \& Bennett, R. J. 1995. A typology of deviant workplace behaviors: a multidimensional scaling study. Academy of Management Journal, 38, 555-572.

Robinson, S. L., \& O’Leary-Kelly, A. M. (1998). Monkey see, monkey do: The influence of work groups on the antisocial behavior of employees. Academy of Management Journal, 41, 658-672.

Rime', B. (2007). The social sharing of emotion as an interface between individual and collective processes in the construction of emotional climates. Journal of Social Issues, 63, 307-322.

Salancik, G. R., \& Pfeffer, J. 1978. A social information processing approach to job attitudes and task design. Administrative Science Quarterly, 23: 224-253.

Sattler dan Kerr, 1991; Satttler, D. N., \& Kerr, N. 1991. Might versus morality explored: Motivational and cognitive bases of social motives. Journal of Personality and Social Psychology, 60: 756-765.

Scott, G.S., \& Einstein, O.W. 2001. Strategic performance appraisal inteam-based organizations One size does not fit all - Academy ol Management Executive. Vol. 15, No. 2.
Shaw, J. D., Zhu, Jing., Duffy, Michelle K., Scott, Kristin L., Shih, Hsi-An, \& Susanto, Ely. 2011. A Contingency Model of Conflict and Team Effectiveness. Journal of Applied Psychology. Vol. 96, No. 2, 391-400

Sherif, M. 1935. A study of some social factors in perception. Archives of Psychology, 27(187): 23-46.

Shore, L. M, Tetrick, L. E., Lynch, P. \& Barksdale, K. 2006. Social and Economic Exchange: Construct Development and Validation. Journal of Applied Social Psychology, 36(4), 837-867.

Shrivastava, A. \& Purang, P. 2011. Employee perceptions of performance appraisals: a comparative study on Indian banks, The International Journal of Human Resource Management, Vol. 22, No. 3, January 2011, 632-647

Somech, A., Desivilya, H.S., \& Lidogoster, H. 2009. Team conflict management and team effectiveness: the effects of task interdependence and team identification. Journal of Organizational Behavior, 30, 359-378.

Thurston, P.W. Jr. (2001), 'Clarifying the structure of justice using fairness perceptions of Performance Appraisal practices,' unpublished Ph.D. dissertation, Albany, NY.

Totterdell, P., Kellett, S., Teuchmann, K., \& Briner, R. 1998. Evidence of mood linkage in work groups. Journal of Personality and Social Psychology, 74: 1504-1515.

Tsui, Egan, dan O'Reilly, 1992) Tsui, A. S., Egan, T. D., \& O'Reilly, C. A. 1992. Being different: Relational demography and organizational attachment. Administrative Science Quarterly, 37: 549-577. 
Van Lange, P. A. M., Kuhlman, D. M. 1994. Social value orientations and impressions of partner's honesty and intelligence: A test of the might versus morality effect. Journal of Personality and Social Psychology, 67: 126-141.
Yukl, G., \& Falbe, C.M. 1991. Importance of different power sources in downward and lateral relations. Journal of Applied Psychology, 76: 416-423.

Yukl, G., Kim, H., \& Falbe, C. M. 1996. Antecedents of influence outcomes. Journal of Applied Psychology, 81: 309-317. 